\title{
One Health Approach: The key to addressing pandemics and other complex challenges of the $21^{\text {st }}$ Century
}

The corona virus infectious disease or Covid 19 pandemic has been causing unprecedented loss of lives and livelihoods across the globe. This is the third time a Beta coronavirus has crossed the animalhuman species barrier in the last 20 years resulting in a major zoonotic outbreak [1]. The first was in 2002, when the SARS CoV-1 virus caused an outbreak in China and second was in 2012 with the MERS CoV causing an outbreak in the Middle East. The SARS CoV1 originated from bats and the MERS CoV originated from camels. Covid 19 disease is a zoonotic infection caused by SARS CoV-2 virus, which originated in Wuhan city in China in December 2019, which quickly spread across the world. The zoonotic source of SARS CoV-2 is not known but is closely related to a group of SARS CoV viruses found in bats a, humans and civets [2].

The complex challenges of the $21^{\text {st }}$ century like climate change and the recent disease outbreaks are evidence of increased human animal interactions and human influence which will continue to increase, given the increasing human demand for space, food and unbridled consumerism. They also are an indicator of the interconnectedness of human and animal and environmental health. Hippocrates, the great Greek physician in his book 'On air, waters and places' had dwelled on the importance of relationship between human health and the environment [3]. The 'One Health' approach recognizes this important relationship between human, animal and environmental health. In 2004, the wildlife conservative society with a group of partner organizations launched the 'the one world, one health 'initiative which was the primary step in the evolution of the modern concept of One Health [3]. One health is defined by the One Health High Level Expert Panel (OHLLEP) as "an integrated, unifying approach that aims to sustainably balance and optimize the health of people, animals and ecosystems" [4].

The one health approach calls upon human medicine, veterinary medicine, public health, environmental sciences, and a host of other disciplines to work together to improve the health of humans, animals and the environment. The scope of one health includes areas such as climate change, biodiversity loss, food, and water security, emerging and reemerging diseases, antimicrobial resistance etc....

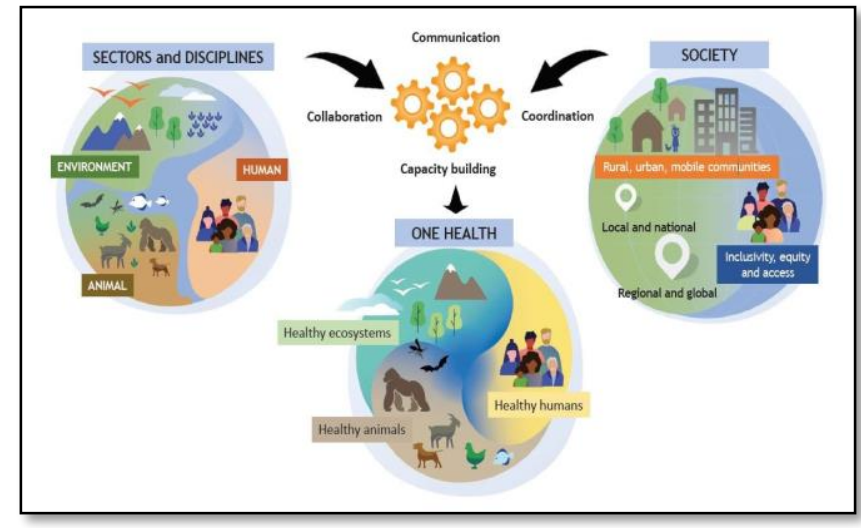

Image source: https://www.who.int [4]

The key strategies of One health for the prevention and control of zoonotic diseases are as follows $[3,5]$.

1. Surveillance of disease or infections in wildlife, livestock and human populations including environmental surveillance.

2. Minimizing human -animal interactions and spread of infections from animals to humans - for example safe handling of livestock, pets and wildlife, livestock vaccinations etc...

3. Reducing antimicrobial resistance through rational antibiotic use in animals and livestock.

Article Summary: Submitted: 22-October-2021 Revised: 06-November-2021 Accepted: 03-December-2021 Published: 31-December-2021

\begin{tabular}{|c|c|c|}
\hline Quick Response Code: & \multirow{3}{*}{$\begin{array}{l}\text { Web Site } \\
\text { http://ijmsnr.com/ }\end{array}$} & \multirow{2}{*}{$\begin{array}{l}\text { This is an open access journal, and articles are distributed under the terms of the } \\
\text { Creative Commons Attribution-Non-Commercial-ShareAlike } 4.0 \text { International } \\
\text { License, which allows others to remix, tweak, and build upon the work } \\
\text { non-commercially, as long as appropriate credit is given and the new creations are } \\
\text { licensed under the identical terms. }\end{array}$} \\
\hline & & \\
\hline & & $\begin{array}{l}\text { How to cite this article: Priyanka Raj C K. One Health Approach: The } \\
\text { key to addressing pandemics and other complex challenges of the } 21^{\text {st }} \\
\text { Century. Int J Med Sci and Nurs Res } 2021 ; 1(2): 1-2 \text {. }\end{array}$ \\
\hline
\end{tabular}


4. Integrating and coordinating disease prevention, surveillance and response across all sectors (animal husbandry, education, health, communications, agriculture etc....)

5. Addressing climate change at local, national, and international levels.

6. Promoting collaborative research

These strategies have been effective in controlling SARS CoV outbreak in 2002 by banning of trade of civet cats [6]. One health strategies also helped in reducing the MERS CoV case fatalities [7]. In Chad, simultaneous human and animal vaccinations have proven effective against brucellosis [8].

We are facing complex challenges with regard to climate change, emerging and reemerging diseases, food and water security and individual responses are incapable of addressing these issues and the only way to deal with these complex issues is to collaborate and coordinate our efforts across disciplines, sectors and nations. Barriers to implementing One health do exist, but One Health approach is the key to ensure sustainability and survivability of all life on planet earth.

\section{References:}

1. Schmiegea D, Arredondo AMP, Ntajal J, Paris JMG, Savi MK, Patel $\mathrm{K}$, et al. One Health in the context of coronavirus outbreaks: A systematic literature review. One Health. 2020;10:1-9. DOI: https://doi.org/10.1016/j.onehlt.2020.100170

2. World Health Organization: WHO Coronavirus (COVID-19) Dashboard. Available from: https://covid19.who.int/ [Accessed on: 10 August 2021]

3. Katz DL, Elmore JG, Wild D, Lucan SC. Jekel's Epidemiology, biostatistics, preventive medicine and public health. $4^{\text {th }}$ edition 2014:364-377. Elsevier Saunders. ISBN-13: 978-1455706587

Publish your research articles with

International Journal of Medical Sciences and Nursing Research Website: http://ijmsnr.com/
4. WHO: Tripartite and UNEP support OHHLEP's definition of "One Health". Available from: https://www.who.int/news/item/01-12-2021-tripartite-andunep-support-ohhlep-s-definition-of-one-health [Accessed on: $25^{\text {th }}$ August 2021]

5. Hamida MG, Ba Abdullah MM. The SARS-CoV-2 outbreak from a one health perspective. One Health. 2020;10:100127.

DOI:

https://doi.org/10.1016/j.onehlt.2020.100127

6. Parry J. WHO queries culling of civet cats. BMJ 2004;328(7432):128.

7. Hemida MG, Alnaeem A. Someone health-based control strategies for the middle east respiratory syndrome coronavirus, One Health 2019;8:100102. PMID: 31485476

8. Roth J, Zinsstag J, Orkhon D, Chimed-Ochir G, Hutton G, Cosivi O, et al. Human health benefits from livestock vaccination for brucellosis; case study. Bulletin WHO 2003;81:867-876.

\section{Dr. C. K. Priyanka Raj,}

Deputy Editor-In-Chief, IJMSNR, Associate Professor. Department of Public Health and Epidemiology, College of Medicine and Health Sciences, Sohar, National University of Science and Technology, Sultanate of Oman.

Email ID: priyankaraj@nu.edu.om and DeputyEditor-in-chief@ijmsnr.com 